\title{
Genes associated with rheumatoid arthritis and mild inflammatory arthritis. II. Association of HLA with complement $\mathrm{C} 3$ and immunoglobulin $\mathrm{Gm}$ allotypes
}

\author{
Alison H Puttick, D C Briggs, K I Welsh, Elizabeth A Williamson, R K Jacoby, \\ Valerie E Jones
}

\begin{abstract}
Associations were sought between major histocompatibility complex (MHC) genes on chromosome 6 and the complement component $\mathrm{C} 3$ and immunoglobulin genes located on other chromosomes which might contribute to susceptibility to mild inflammatory arthritis (IA) or definite rheumatoid arthritis (RA). Frequencies of the complement $\mathrm{C} 3 \mathrm{~F}$ allele were raised in patients with IA but were normal in patients with RA and controls. When associations between $\mathrm{C} 3 \mathrm{~F}$ and MHC genes were sought frequencies of some MHC genes were greater in patients with $\mathrm{C} 3 \mathrm{~F}$ than in those without-for example, HLA-B8 and DR3 in patients with $R A$ and $D R 2$ in patients with IA. Conversely, DR4 frequency was lower in patients with IA with C3F than in those without. Thus the C3F allele may act independently or exert an epistatic effect on MHC genes to increase susceptibility or protect against disease.

The frequency of the immunoglobulin heavy chain allotype $G \operatorname{lm}(2)$ on chromosome 14 was increased in patients with RA but only in those with the phenotype $\mathrm{Gml}, 2,3,17 ; 21,5$; no significant associations were found between MHC genes and $\mathrm{Gm}$ phenotypes. Further, no associations of $\mathrm{MHC}, \mathrm{C} 3 \mathrm{~F}$, and immunoglobulin genes were shared by patients with RA and those with IA, indicating a different genetic basis for the two clinical entities.
\end{abstract}

In the accompanying paper $^{1}$ we confirmed the strong association of HLA-DR4 with definite rheumatoid arthritis (RA) and showed that patients with mild inflammatory arthritis (IA), which included patients who would be classified as 'possible' or 'probable' RA by earlier definitions, ${ }^{2}{ }^{3}$ were not associated with DR4. HLA antigens associated with IA were found at the $A$ and $B$ loci, not at the DR locus, and major histocompatibility complex (MHC) associations with RA and IA did not appear to overlap.

Because the association of RA with DR4 and related $\mathrm{MHC}$ antigens is incomplete ${ }^{4}$ associations have been sought with genes on other chromosomes. Attempts to associate RA with complement component C3 genes, located on chromosome 19, and the immunoglobulin heavy chain genes $(\mathrm{Gm})$ on chromosome 14 , have produced conflicting results. These results were summarised by Thomson et al, who concluded that there is little evidence that C3 alleles predispose to $\mathrm{RA}$, whereas genes linked to $\mathrm{Gm}$ may predispose to RA but only by interaction with HLA alleles. ${ }^{5}$
In this paper we have compared the frequencies of $\mathrm{C} 3$ and $\mathrm{Gm}$ alleles in patients with RA and IA and sought interactions of these alleles with the MHC genes associated with RA. Our aim was to discover if other genes as well as those in the MHC might (a) predispose to RA, (b) predispose to mild inflammatory arthritis, or (c) protect patients with IA from developing definite RA. In patients with RA we found some associations between the $\mathrm{C} 3 \mathrm{~F}$ allele of the complement component $\mathrm{C} 3$ and $\mathrm{MHC}$ genes; an association was also found between RA and the $\mathrm{Gm}$ allotype $\mathrm{Glm}(2)$. The $\mathrm{C} 3 \mathrm{~F}$ allele may also be relevant in patients with IA, particularly when associated with HLA-B62, DR4, or DR2.

\section{Patients and methods}

PATIENTS

The 61 patients with RA who were typed for MHC antigens, complement component C3, and $\mathrm{Gm}$ allotypes are described in the accompanying paper. ${ }^{1}$ Thirty five additional patients with definite or classical $\mathrm{RA}^{2}{ }^{3}$ were included in the study on $\mathrm{Gm}$ allotype frequencies; no MHC or complement allotypes were determined in these patients.

Similarly, 49 patients with IA typed for MHC, C3, and $\mathrm{Gm}$ allotypes, are also described in the accompanying paper. ${ }^{1}$ Fifty six additional patients with IA were $\mathrm{Gm}$ allotyped; three of these were also typed for MHC and C3 allotypes.

\section{CONTROLS}

HLA frequencies were obtained from Exeter donors as already described. ${ }^{1}$ Allotype frequencies of the complement component $\mathrm{C} 3$ were measured in 304 donors in the Tissue Typing Laboratory at Guy's Hospital and 34 of these were also tissue typed for HLA-A and B antigens. Frequencies of $\mathrm{Gm}$ allotypes but not HLA or C3 were measured in 94 Exeter donors.

\section{TISSUE TYPING}

The major allotypes of the complement component $\mathrm{C} 3$-namely, $\mathrm{F}$ and $\mathrm{S}$-were measured by the method of Alper and Propp. ${ }^{6}$ The rare C3 allotypes-namely, FO.5, SO.5, FO.8, and SO.25-were omitted from our analyses. Immunoglobulin $\mathrm{Gm}$ and $\mathrm{Km}$ allotypes were measured with reagents purchased from the Central Laboratory of the Netherlands, Amsterdam, using methodology described by van Loghem. ${ }^{7}$ Serum samples which reacted strongly with antibody coated erythrocytes were separated by gel filtration and the IgG fraction was 
allotyped. Alternatively, serum samples were treated with dithiothreitol before allotyping. Thus no patients or controls were excluded because of anti-IgG activity. Typing of HLA-A $B$, and DR antigens, complement components $\mathrm{C} 4 \mathrm{~A}, \mathrm{C} 4 \mathrm{~B}$, and $\mathrm{Bf}$, and glyoxalase-1 allotypes was carried out as before. ${ }^{18}$

STATISTICAL ANALYSIS

Differences in allele or phenotype frequencies between patient and control populations were assessed for statistical significance with the $\chi^{2}$ test, using Yates's correction for small numbers. Numbers of individuals or chromosomes included in each analysis are given in the relevant table.

\section{Gm NOMENCLATURE}

Where reference is made to $\mathrm{Gm}$ phenotypes the immunoglobulin isotype of each $\mathrm{Gm}$ allotype has been omitted. Thus $\operatorname{Glm}(1,17) ; \mathrm{G} 3 \mathrm{~m}(21)$ is expressed as $\mathrm{Gml}, 17 ; 21$.

\section{Results}

COMPLEMENT C

In patients with $\mathrm{RA}$ frequencies of the C3 phenotypes FF, SF, and SS, and the F and $S$ allotype and gene frequencies were similar to controls. In patients with IA the FF phenotype and $\mathrm{C} 3 \mathrm{~F}$ gene frequencies were raised, though not significantly (FF phenotype: IA $14 \cdot 0 \%$, RA $6 \cdot 1 \%$, controls $6.9 \%$; C3F gene: IA $29 \cdot 4 \%$, RA $20 \cdot 6 \%$, controls $22 \cdot 0 \%$ ).

HLA AND C3

When patients were divided into those with and those without $\mathrm{C} 3 \mathrm{~F}$ some significant differences emerged (table 1). In patients with RA the frequencies of $\mathrm{B} 8$ and DR3 genes were higher in $\mathrm{C} 3 \mathrm{~F}$ positive than in $\mathrm{C} 3 \mathrm{~F}$ negative patients. In patients with IA the frequency of DR2 was higher and of DR4 lower in $\mathrm{C} 3 \mathrm{~F}$ positive than in C3F negative patients. HLA gene frequencies in $\mathrm{C} 3 \mathrm{~F}$ positive patients with $\mathrm{RA}$ also differed from $\mathrm{C} 3 \mathrm{~F}$ positive patients with IA and from Exeter controls, though not all differences were significant (table 1). HLA gene frequencies were also measured in 34 donors from Guy's Hospital with known $\mathrm{C} 3$ allotypes $(\mathrm{C} 3 \mathrm{~F}$ positive $=18$ chromosomes; $\mathrm{C} 3 \mathrm{~F}$ negative $=50$ chromosomes); frequencies of HLA-B8 genes were $16.7 \%$ and $10.0 \%$, for B40 were $<5.6 \%$ and $4.0 \%$, and for $\mathrm{B} 62$ were $11 \cdot 1 \%$ and $6.0 \%$ respectively. Numbers were too few, however, for statistical analysis.

Analysis of MHC genes associated with IAnamely, A24, A25, B27, B35, C4A4 and DR5in $\mathrm{C} 3 \mathrm{~F}$ positive and negative patients showed no interaction. For example, of the five patients with IA with HLA-A25, three were $\mathrm{C} 3 \mathrm{~F}$ positive and two were negative.

\section{IMMUNOGLOBULIN Gm}

When patients with homozygous $\mathrm{Gm}$ phenotypes were compared frequencies were similar in patients with RA, patients with IA, and controls (table 2). In heterozygous patients, however, the frequency of $\mathrm{Gml}, 2,3,17 ; 21,5$ was significantly greater in RA than in patients with IA and, presumably in compensation, the frequency of $\mathrm{Gml}, 3,17 ; 21,5$ was lower in RA than in patients with IA or controls. Thus the frequency of $\mathrm{Glm}(2)$ is significantly increased in RA, but only in patients with RA heterozygous for $\mathrm{Gm}$ allotypes. No other significant

Table 1: Interaction of HLA genes with the C3F antigen in patients with rheumatoid arthritis and inflammatory arthritis. The frequency (\%) of HLA genes is shown

\begin{tabular}{|c|c|c|c|c|c|c|c|c|c|}
\hline \multirow{2}{*}{$\begin{array}{l}\text { HLA } \\
\text { genes }\end{array}$} & \multicolumn{3}{|c|}{ Patients with $R A^{*}$} & \multicolumn{3}{|c|}{ Patients with IA* } & \multirow{2}{*}{$\begin{array}{l}\text { Controls } \\
\text { total } \\
(n=276)\end{array}$} & \multicolumn{2}{|c|}{ Significance } \\
\hline & $\begin{array}{l}\text { Total } \\
(n=112)\end{array}$ & $\begin{array}{l}C 3 F+ \\
(n=40)\end{array}$ & $\begin{array}{l}C 3 F- \\
(n=72)\end{array}$ & $\begin{array}{l}\text { Total } \\
(n=104)\end{array}$ & $\begin{array}{l}C 3 F+ \\
(n=46)\end{array}$ & $\begin{array}{l}C 3 F- \\
(n=58)\end{array}$ & & $\chi^{2}$ & $p$ \\
\hline$\overline{\mathrm{B} 8}$ & $18 \cdot 8$ & $32 \cdot 5^{a b}$ & $11 \cdot 1^{2}$ & $12 \cdot 5$ & $15 \cdot 2$ & $10 \cdot 3$ & $14 \cdot 9^{b}$ & $\begin{array}{l}\text { a } 7 \cdot 25 \\
\text { b7.68 }\end{array}$ & $\begin{array}{l}<0.01 \\
<0.01\end{array}$ \\
\hline $\begin{array}{l}\text { B40 } \\
\text { B62 }\end{array}$ & $\begin{array}{r}9 \cdot 8 \\
15 \cdot 2\end{array}$ & $\begin{array}{l}15 \cdot 0^{c} \\
20 \cdot 0^{d e}\end{array}$ & $\begin{array}{r}6.9 \\
12.5\end{array}$ & $\begin{array}{l}3 \cdot 8 \\
5 \cdot 8\end{array}$ & $\underset{2 \cdot 2 \cdot 2^{\mathrm{c}} \dagger}{2 \cdot}$ & $\begin{array}{l}6.9 \\
8 \cdot 6\end{array}$ & $\begin{array}{l}6 \cdot 5 \\
8 \cdot 3^{e}\end{array}$ & $\begin{array}{l}\text { c5.29 } \\
\text { d5.48 } \\
\text { e5.52 }\end{array}$ & $\begin{array}{l}<0.05 \\
<0.02 \\
<0.02\end{array}$ \\
\hline DR2 & $7 \cdot 1$ & $5 \cdot 0^{f}$ & $8 \cdot 3$ & $16 \cdot 3$ & $26 \cdot 1^{f g}$ & $8 \cdot 6^{8}$ & $\begin{array}{l}(n=252) \\
15 \cdot 5\end{array}$ & $\begin{array}{r}f_{5.51} \\
84.52\end{array}$ & $\begin{array}{l}<0.02 \\
<0.05\end{array}$ \\
\hline $\begin{array}{l}\text { DR3 } \\
\text { DR4 }\end{array}$ & $\begin{array}{l}10 \cdot 7 \\
48 \cdot 7\end{array}$ & $\begin{array}{l}20 \cdot 0^{\mathrm{h}} \\
55 \cdot 0^{\mathrm{i}}\end{array}$ & $\begin{array}{c}5 \cdot 6^{h} \\
44 \cdot 4^{h}\end{array}$ & $\begin{array}{l}15 \cdot 4 \\
26 \cdot 9\end{array}$ & $\begin{array}{l}19 \cdot 6 \\
13 \cdot 0^{i} i\end{array}$ & $\begin{array}{l}12 \cdot 1 \\
37 \cdot 9 \mathrm{j} \mathrm{k}\end{array}$ & $\begin{array}{l}15 \cdot 1 \\
21 \cdot 0^{k}\end{array}$ & $\begin{array}{r}\text { h. } 4 \cdot 67 \\
\text { i } 15 \cdot 29 \\
16 \cdot 86 \\
\text { k7.34 }\end{array}$ & $\begin{array}{l}<0.05 \\
<0.001 \\
<0.01 \\
<0.01\end{array}$ \\
\hline
\end{tabular}

${ }^{*} \mathrm{RA}=$ rheumatoid arthritis; $\mathrm{IA}=$ inflammatory arthritis; $\mathrm{n}=$ number of chromosomes †No patient carried this gene.

Table 2: Immunoglobulin $\mathrm{Gm}$ phenotype frequencies (\%) in patients with rheumatoid arthritis and inflammatory arthritis

\begin{tabular}{|c|c|c|c|c|c|}
\hline \multirow{2}{*}{$\begin{array}{l}\text { Gm } \\
\text { phenotypes }\end{array}$} & \multirow{2}{*}{$\begin{array}{l}\text { Patients with } \\
R A^{*} \\
(n=96)\end{array}$} & \multirow{2}{*}{$\begin{array}{l}\text { Patients with } \\
I A^{*} \\
(n=105)\end{array}$} & \multirow{2}{*}{$\begin{array}{l}\text { Controls } \\
(n=94)\end{array}$} & \multicolumn{2}{|c|}{ Significance } \\
\hline & & & & $\bar{x}^{2}$ & $p$ \\
\hline $\begin{array}{l}\mathrm{Gml} 1,17 ; 21 \\
\mathrm{Gml}, 2,17 ; 21 \\
\mathrm{Gm} 3 ; 5 \\
\mathrm{Gml}, 3,17 ; 21,5 \\
\text { Gm1,2,3,17;21,5 } \\
\text { Glm(2) allotype }\end{array}$ & $\begin{array}{l}3 \cdot 1 \\
7 \cdot 3 \\
42 \cdot 7 \\
24 \cdot 0 \\
22 \cdot 9^{\mathrm{a}} \\
30 \cdot 2^{\mathrm{b}}\end{array}$ & $\begin{array}{c}6 \cdot 7 \\
7 \cdot 6 \\
44 \cdot 7 \\
30 \cdot 5 \\
11 \cdot 4^{\mathrm{a}} \\
19 \cdot 0\end{array}$ & $\begin{array}{l}5 \cdot 3 \\
5 \cdot 3 \\
43 \cdot 6 \\
32 \cdot 9 \\
12 \cdot 7 \\
18 \cdot 1^{b}\end{array}$ & $\begin{array}{l}23.93 \\
b_{4} \cdot 18\end{array}$ & $\begin{array}{l}<0.05 \\
<0.05\end{array}$ \\
\hline
\end{tabular}

${ }^{*} \mathrm{RA}=$ rheumatoid arthritis; $\mathrm{IA}=$ inflammatory arthritis; $n=$ number of subjects. 
differences in $\mathrm{Gm}$ frequencies were found, either between patients seropositive or seronegative for rheumatoid factor, or between male and female patients. There was a small but not significant increase in the kappa light chain allotype $\mathrm{Kml}$ in patients with $\mathrm{RA}$ compared with patients with IA and controls.

HLA AND Gm

Because differences were found in $\mathrm{Gm}$ heterozygous patients with RA, frequencies of HLA antigens and genes were compared in patients with $\mathrm{Gml}, 2,3,17 ; 21,5$ and $\mathrm{Gml}, 3,17 ; 21,5$ phenotypes. Differences in HLA frequencies were found but numbers of patients were too few for statistical significance. For example, the frequency of HLA-B7 in all patients with IA was similar to that in controls but none of five patients with IA with $\mathrm{Gml}, 2,3,17 ; 21,5 \mathrm{had}$ B7, whereas eight of 15 patients with IA with $\mathrm{Gml}, 3,17 ; 21,5$ carried B7, suggesting an association of $B 7$ with $\mathrm{Gml}, 3,17 ; 21,5$ in patients with IA.

There was no significant difference between the frequency of DR4 genes in $\mathrm{Glm}(2)$ positive and negative heterozygous patients (RA $38.3 \%$ and $60.0 \%$ respectively) or between the frequency of the $\mathrm{Gml}, 2,3,17 ; 21,5$ phenotype in DR4 positive and negative patients (RA 23.9\% and $45.5 \%$ respectively), but the results suggest that the $\mathrm{Gml}, 2,3,17 ; 21,5$ phenotype is more important in RA when DR4 is absent. The $\mathrm{Gml}, 2,3,17 ; 21,5$ phenotype plus DR4 may also increase susceptibility to RA in men. Eleven of the 12 male patients with RA were $\mathrm{DR} 4$ positive and six of these carried the $\mathrm{Gml}, 2,3,17 ; 21,5$ phenotype. In contrast, six of the 10 male patients with IA were DR4 positive but none carried $\mathrm{Glm}(2)$.

\section{GLYOXALASE-1}

Associations between frequencies of HLA antigens and glyoxalase allotypes were sought. Associations were also sought between $\mathrm{C} 3$ and $\mathrm{Gm}$ allotypes. No significant differences were found in patients with RA or IA in any comparison.

\section{Discussion}

Previous studies in Europe on the associations of complement C3 polymorphisms with $\mathrm{RA}$ have given conflicting results. Early reports suggested that the C3FF phenotype ${ }^{9}$ and $\mathrm{C} 3 \mathrm{~F}$ gene $^{10}$ were important in RA, but later studies failed to confirm this association. ${ }^{11-13}$ Indeed, Thomson et al noted that in both early studies the C3F gene frequency, though raised, still lay within the expected range for normal European populations $(0.14-0.257$, summarised in ref 14). ${ }^{12}$ The $C 3 F$ gene frequencies in our patients with RA and controls were also within this range but the frequency in our patients with IA was higher. Discrepancies between the various studies might be explained by clinical ascertainment of RA because Brönnestam, ${ }^{10}$ for example, included 'probable' RA and a high proportion (38\%) of patients seronegative for rheumatoid factor. Brönnestam found that the $\mathrm{C} 3 \mathrm{~F}$ gene frequency was highest in patients without RA with the highest titres of rheumatoid factor but that the frequency in seropositive patients without RA was lower than that in controls; he therefore concluded that the $\mathrm{C} 3 \mathrm{~F}$ gene was associated with a clinical diagnosis of RA but not with the occurrence of rheumatoid factor. In our study a distinction was drawn between patients with RA (definite or classical), of whom $81 \%$ were seropositive, and patients with IA, who included those classified as 'possible' or 'probable' RA, of whom $92 \%$ were seronegative. Thus we suggest that the $\mathrm{C} 3 \mathrm{~F}$ gene is more likely to be a marker for mild self-limiting seronegative arthritis than for seropositive definite RA.

The associations found between HLA genes and $\mathrm{C} 3 \mathrm{~F}$ in patients with $\mathrm{RA}$ and those with IA are more difficult to interpret. Thomson et al compared the frequencies of $\mathrm{C} 3$ genetic variants in DR4 positive and DR4 negative patients but detected no associations of C3 with DR4 in RA. ${ }^{12}$ A similar analysis of our patients also showed no associations, partly because too few of our patients with RA (12) were DR4 negative. The converse method of analysis-namely, comparison of the frequency of DR4 genes in $\mathrm{C} 3 \mathrm{~F}$ positive and $\mathrm{C} 3 \mathrm{~F}$ negative patients with RA-also failed to show an association between C3F and DR4. Further analysis of HLA gene frequencies in $\mathrm{C} 3 \mathrm{~F}$ positive and negative patients, however, showed several distinctive features. Firstly, HLA-B8 and DR3, which are in linkage disequilibrium and are associated with other autoimmune diseases, were not raised overall in patients with RA but were associated with C3F positive patients with RA. Secondly, DR2, which was low in our patients with RA and is considered to be protective in $\mathrm{RA},{ }^{4}$ was associated with IA in $\mathrm{C} 3 \mathrm{~F}$ positive patients. Thirdly, some gene frequencies-notably, B40, B62, and DR4 - which were high in C3F positive patients with $\mathrm{RA}$ were unexpectedly low in $\mathrm{C} 3 \mathrm{~F}$ positive patients with $\mathrm{IA}$; this suggests an inverse relation between $\mathrm{RA}$ and IA in their association of C3F with HLA genes and emphasises the genetic differences already reported between patients with $R A$ and those with IA. ${ }^{1}$ All three HLA genes are implicated in $\mathrm{RA}$ in their own right, irrespective of $\mathrm{C} 3,{ }^{15}$ therefore $\mathrm{C} 3 \mathrm{~F}$ may have an independent role in conferring susceptibility or protection in both clinical situations.

The significantly increased frequencies of both $\mathrm{Glm}(2)$ and the $\mathrm{Gm}$ phenotype $\mathrm{Gml}, 2,3,17 ; 21,5$ in patients with RA confirmed our preliminary study. ${ }^{8}$ Many, but not all, studies have reported associations of $\mathrm{Glm}(2)$ with $R A$ and in three of these $\operatorname{Glm}(2)$ was associated with DR4 positive RA (summarised in ref 16). In these reports, however, frequencies of $\mathrm{Gm}$ phenotypes containing $\mathrm{Glm}(2)$ and their importance in RA vary considerably. Indeed one study on seropositive RA found that $\mathrm{Gml}$, $2 ; 21$ was increased and $\mathrm{Gml}, 2,3 ; 21,5$ was decreased in $\mathrm{RA},{ }^{16}$ the converse of our results. The association of $\mathrm{Glm}(2)$ with DR4 positive RA was not confirmed in our patients because the sample size of DR4 negative patients was too small. Our results suggest the opposite, however, that $\operatorname{Glm}(2)$ and the $\mathrm{Gml} 1,2,3,17 ; 21,5$ 
phenotype are more important in susceptibility to RA in the absence of other strongly predisposing factors such as DR4 and the female susceptibility gene. In patients with IA no associations of HLA genes with Gm markers were significant, though B7 may be important in the absence of $\mathrm{Glm}(2)$. In patients with IA, furthermore, $\mathrm{C} 3 \mathrm{~F}$ showed no interaction with any HLA-A and B locus genes associated with IA, ${ }^{1}$ including the rare allele A25.

Now that RA has been redefined ${ }^{2}$ the clinical distinction between RA and IA has been clarified, but in the earliest stages the clinical symptoms of RA and IA are often indistinguishable ${ }^{17}$ and genetic markers might aid disease prognosis. None of the genes studied here, however, is sufficiently strongly represented in either patient group to provide an accurate screening method for individual patients at onset of arthritis.

For the purposes of genetic analysis in this and the accompanying paper ${ }^{1}$ we have assumed that both RA and IA are homogeneous disease entities, but this assumption is valid only for clinical presentation. At present there is no strong evidence for or against the hypothesis that RA is induced by a single aetiological agent. But IA can be provoked by a number of different viruses and other agents-for example, we found evidence of $\mathrm{B} 19$ parvovirus infection in only five of our patients with IA. ${ }^{1}$ Therefore the similar clinical features in patients with IA are not related to a single primary inducing agent. Nevertheless, our analysis does emphasise the difference in genetic background between mild self-limiting arthritis and the chronic severe arthritis of definite RA. In patients with $R A$, however, it is still not possible to distinguish between genetic markers for an aetiological agent and markers for risk of chronic arthritis.
1 Puttick A H, Briggs D C, Welsh K I, et al. Genes associated with rheumatoid arthritis and mild inflammatory arthritis. I. Major histocompatibility complex class I, II, and III allotypes. Ann Rheum Dis 1990; 49: 219-24.

2 Arnett F C, Edworthy S M, Bloch D A, et al. The American Rheumatism Association 1987 revised criteria for the classification of rheumatoid arthritis. Arthritis Rheum 1988; 31: 315-24.

3 Ropes M W, Bennett G A, Cobb S, Jacox R, Jessar R A. 1958 Revision of diagnostic criteria for rheumatoid arthritis. Bul Rheum Dis 1958; 9: 175-6.

4 Lanchbury J S S. Molecular genetics of the HLA-D region component of inherited susceptibility to rheumatoid arthritis. $B r \mathcal{F}$ Rheumatol 1988; 27: 171-5.

5 Thomson W, Dyer P A, Sanders P A, Grennan D M. C3, Gm and $\mathrm{Pi}$ polymorphisms in rheumatoid arthritis. Dis Markers $1986 ; 4: 145-50$.

6 Alper C A, Propp R P. Genetic polymorphism of the third component of human complement (C3). $\mathcal{F}$ Clin Invest 1968; 47: 2181-91.

7 van Loghem E. Genetic studies on human immunoglobulins. In: Weir D M, ed. Handbook of experimental immunology. Vol I. Oxford: Blackwell Scientific, 1978: 11, 1-16.

8 Puttick A H, Briggs D, Welsh K, Jacoby R K, Williamson E A, Jones V E. Extended haplotypes in rheumatoid arthritis and preliminary evidence for interaction with immunoglobulin preliminary evidence for interaction
genes. Dis Markers $1986 ; 4: 139-44$.

9 Farhud D D, Ananthakrishnan R, Walter H. Association between $C^{\prime} 3$ phenotypes and various diseases. Humangenetik 1972; 17: 57-60.

10 Brönnestam R. Studies of the C3 polymorphism. Relationship between $\mathrm{C} 3$ phenotypes and rheumatoid arthritis. Hum Hered 1973; 23: 206-13.

11 Dahlqvist R S, Beckman G, Beckman L. Bf and C3 complement types in rheumatoid arthritis. Hum Hered 1985 35: $240-5$.

12 Thomson W, Dyer P A, Sanders P A, Grennan D M. Genetic variants of complement component 3 (C3) in DR4 positive and DR4 negative rheumatoid arthritis. Ann Rheum positive and DR4 negativi

13 Lanchbury J S S, Pal B, Papiha S S. Bf and C3 polymorphisms in rheumatoid arthritis. Hum Hered 1987; 37: 144-9.

14 Wyatt R J, Julian B A, Galla J H, McLean R H. Increased frequency of $\mathrm{C} 3$ fast alleles in IgA nephropathy. Dis Markers 1984; 2: 419-28.

15 Woodrow J C. Analysis of the HLA association with rheumatoid arthritis. Dis Markers 1986; 4: 7-12.

16 Zarnowski H, Mierau R, Werdier D, Antons M, Genth E, Hartl $P$ W. Increased frequency of $\mathrm{Gm}(1,2 ; 21)$ phenotype in HLA-DR4 positive seropositive rheumatoid arthritis. f Rheumatol 1986; 13: 858-63.

17 Jones V E, Jacoby R K, Johnson P M, Phua K K, Welsh K I Association of HLA-DR4 with definite rheumatoid arthritis but not with susceptibility to arthritis [Abstract]. Ann Rheum Dis 1983; 42: 223. 